\title{
Formulation and in vitro characterization of spray dried microspheres of amoxicillin
}

\author{
JIGNYASHA A. RAVAL ${ }^{1, *}$ \\ JAYVADAN K. PATEL ${ }^{2}$ \\ MADHABHAI M. PATEL ${ }^{3}$ \\ 1 S. K. Patel College of Pharmaceutical \\ Education and Research, Ganpat \\ University, Mehsana-Gozaria Highway \\ Kherva-382711, Gujarat, India \\ 2 Nootan College of Pharmacy, Gujarat \\ Technical University, Visnagar-384315 \\ Gujarat, India \\ ${ }^{3}$ Kalol Institute of Pharmacy, Gujarat \\ Technical University, B/h Old Janpath \\ Hotel, National Highway, Kalol-382721 \\ Gujarat, India
}

Accepted October 5, 2010

\begin{abstract}
The purpose of the present study was to design mucoadhesive chitosan microspheres containing amoxicillin. Chitosan microspheres with a small particle size and good sphericity were prepared by a spray-drying method followed by chemical treatment with a chemical crosslinking agent (glutaraldehyde). Parameters affecting the crosslinking extent of the crosslinking time and the concentration of the crosslinker agent. Crosslinked spray-dried chitosan microspheres were analyzed for their morphological aspects, particle size, drug entrapment efficiency, swelling percent and in vitro drug release. Batch M4 with a drug polymer ratio of 1:2, dissolved in minimum concentration of acetic acid solution treated with glutraldehyde, was found to be optimal giving controlled drug release for $10 \mathrm{~h}$. It was found that both the increase of glutaraldehyde concentration and crosslinking duration decreased the swelling capacity of chitosan microspheres. This could be directly correlated to drug release from the microspheres.
\end{abstract}

Keywords: amoxicillin, prolonged/sustained release, chitosan, spray dried microspheres

Amoxicillin is a semi-synthetic, orally absorbed, broad-spectrum antibiotic. It is still widely used in the standard eradication treatment of gastric and duodenal ulcers, which are associated with Helicobacter pylori infection, combined with a second antibiotic and an acid-suppressing agent $(1,2)$. H. pylori, a prevalent human-specific pathogen, is a causative agent in chronic active gastritis (3), gastric and duodenal ulcers (4) and gastric adenocarcinoma (5), one of the most common forms of cancer in humans. The mechanisms by which $H$. pylori may cause gastroduodenal disease and contribute to gastric carcinogenesis are still hypothetical.

Treatment of $H$. pylori remains a challenging proposition. One reason for incomplete eradication of $H$. pylori is probably the short residence time of the dosage form in the stomach so that effective antimicrobial concentration cannot be achieved in the gastric

*Correspondence; e-mail: jignyasha26@yahoo.com 
mucous layer or epithelial cell surfaces where H. pylori exists $(6,7)$. Another reason may be the degradation of amoxicillin in gastric acid (8). A number of researchers have prepared and reported new amoxicillin formulations such as float tablets, mucoadhesive tablets, formulations with $\mathrm{pH}$-sensitive excipients, and others, which are able to reside in the gastrointestinal tract for an extended period of time for more effective $H$. pylori eradication $(9,10)$.

Mucoadhesive microparticles made from the naturally occurring biodegradable polymers like chitosan have attracted considerable attention for several years in sustained drug delivery. Mucoadhesive microspheres/microparticles have advantages such as efficient absorption and enhanced bioavailability of drugs owing to a high surface-to-volume ratio, a much more intimate contact with the mucus layer, and specific targeting of drugs to the absorption site (11-14).

Four main approaches have been proposed: ionotropic gelation with an oppositely charged ion, simple or complex coacervation, emulsification/solvent evaporation and, more recently, spray drying (15). The investigation of chitosan microspheres formation by the spray drying method is justified by interesting results presented in the literature. Chitosan microspheres obtained by this method are characterized by high sphericity and specific surface area (16), important parameters for their application in the pharmaceutical field (drug delivery systems).

In this work, the chemical crosslinking of glutaraldehyde with spray-dried chitosan microspheres is investigated. The method consists of exposure of spray-dried microspheres to the cross-linking agent in the liquid phase and under mild conditions. The effect of the preparation variables (crosslinker concentration and crosslinking duration) was evaluated with regard to the morphological aspect and the swelling behavior of the microspheres.

\section{EXPERIMENTAL}

\section{Materials}

Amoxicillin trihydrate was received as a gift sample from DSM Anti-infective India Limited, India. Chitosan was received as a gift sample from the Central Institute of Fisheries Technology, India. All the other ingredients and chemicals were of analytical grade. All materials used conformed with compendial requirements.

\section{Chitosan microspheres}

Microspheres were prepared by a spray-drying technique. Chitosan solutions were prepared by dissolving chitosan in deionized water containing $0.5 \% \mathrm{~V} / \mathrm{V}$ acetic acid and then adding amoxicillin solution until a clear solution formed under continuous stirring up to $2 \mathrm{~h}$ at $800 \mathrm{rpm}$. The resultant solution was spray dried using LU-222 ADVANCED lab spray drier (Labultima, India) for preparing microspheres. Preliminary batches (with drug to polymer ratio of 1:1) were prepared and evaluated for optimization of process parameters. After optimization of the process parameters, the concentration of chitosan $(0.5,1$ and $2 \%, m / m)$ that would affect the characteristics of spray-dried microspheres was studied. 
Optimization of the formula was done using different ratios (1:1, 1:2, and 1:3) of the drug to chitosan as polymer along with varying concentrations of acetic acid, ranging from 0.5 to $1.5 \%$ (Table I). The flow rate of drying air was maintained at the aspirator setting which indicated the pressure of aspirator filter vessel of -40 mbar. The inlet temperature was maintained at $140{ }^{\circ} \mathrm{C}$, feed rate $6 \mathrm{~mL} \mathrm{~min}^{-1}$, outlet temperature $90{ }^{\circ} \mathrm{C}$, and atomization air pressure $2 \times 10^{5} \mathrm{~Pa}$, as optimized in preliminary trials.

Table I. Formulation composition

\begin{tabular}{cccccccccc}
\hline & M1 & M2 & M3 & M4 & M5 & M6 & M7 & M8 & M9 \\
\hline $\begin{array}{c}\text { Amoxicillin: } \\
\text { chitosan }^{\mathrm{a}}\end{array}$ & $1: 1$ & $1: 1$ & $1: 1$ & $1: 2$ & $1: 2$ & $1: 2$ & $1: 3$ & $1: 3$ & $1: 3$ \\
Acetic acid (\%) & 0.5 & 1.0 & 1.5 & 0.5 & 1.0 & 1.5 & 0.5 & 1.0 & 1.5 \\
\hline
\end{tabular}

a Mass ratio.

\section{Crosslinking of chitosan microspheres}

The microspheres thus obtained were crosslinked with glutaraldehyde to select the solvent, duration of crosslinking $(15,30,60$, and $120 \mathrm{~min})$ and amount of the agent $(5,10$ and $15 \mathrm{~mL}$ glutaraldehyde per $100 \mathrm{mg}$ chitosan). Uncrosslinked microspheres were suspended under magnetic stirring (500 rpm) in $60 \mathrm{~mL}$ of ethanol solution containing glutaraldehyde (35\%) for $120 \mathrm{~min}$. Crosslinked microspheres were filtered, quickly washed with ethanol followed by acetone and then vacuum-dried for at least $24 \mathrm{~h}$.

\section{Viscosity of solution}

The viscosity of chitosan solutions of different concentrations $(0.5,1$ and $2 \%, \mathrm{~m} / \mathrm{m})$ was measured using a Brookfield viscometer, Model No: LVDV-2P230, USA. The spindle used operated at a speed of 30,100 and $10 \mathrm{rpm}$ for $0.5,1$ and $2 \%(\mathrm{~m} / \mathrm{m})$ solution, resp., so as to get maximum torque.

\section{Drug entrapment efficiency}

Efficiency of drug entrapment was calculated in terms of entrapment efficiency (EE). It was determined by crushing $100 \mathrm{mg}$ of accurately weighed microspheres in a glass mortar and then the powdered microspheres were suspended in $10 \mathrm{~mL}$ of $0.1 \mathrm{~mol} \mathrm{~L}^{-1}$ $\mathrm{HCl}$ ( $\mathrm{pH}$ 1.2). After 24 hours, the solution was filtered and the filtrate was analyzed for drug content at the maximum wavelength of $228 \mathrm{~nm}$ using a Systronic 1700 UV spectrophotometer (Japan). Based on the results obtained, the microspheres providing a 200-mg dose were taken for dissolution testing.

\section{Scanning electron microscopy (SEM)}

Scanning electron photomicrographs of chitosan mucoadhesive microspheres were taken. A small amount of microspheres was spread over a metal stub. Afterwards, the 
stub containing the sample was placed in the scanning electron microscope (JSM 5610 LV SEM, JEOL, Japan) chamber. SEM was performed at the acceleration voltage of $20 \mathrm{kV}$, chamber pressure of $80 \mathrm{~Pa}$, at different magnifications.

\section{Particle size of microspheres}

The particle size of microspheres was determined by using a laser particle size analyzer from Brookhaven Instruments Corp., USA. A small amount of dry microspheres was suspended in ethanol $(10 \mathrm{~mL})$. A volume of $2-3 \mathrm{~mL}$ of this suspension was then placed into disposable cells and the particle size was measured with a standard $35 \mathrm{~mW}$ diode laser.

\section{Mucoadhesive property of microspheres}

Mucoadhesive properties of the microspheres were evaluated by the in vitro wash-off test as reported by Lehr et al (11). A piece of rat stomach $(2 \times 2 \mathrm{~cm})$ was tied onto a plastic slide using thread. Microspheres were spread $(\sim 100)$ over the wet rinsed tissue specimen and the prepared slide was hung onto one of the groves of a USP tablet disinegrating test apparatus (17). The disintegrating test apparatus was switched on, whereby the tissue specimen was given regular up and down movements in the beaker of the apparatus, which contained distilled water. At hourly intervals up to 4 hours, the number of microspheres still adhering onto the tissue was counted.

The study was approved by the Institutional Animal Ethics Committee of Ganpat University, India.

\section{Swelling}

Swelling of chitosan microspheres was measured gravimetrically after swelling the microspheres in deionized water $\left(37^{\circ} \mathrm{C}\right)$ at $\mathrm{pH} 6.0$ and measuring the change in their mass after swelling. A certain amount of microspheres were first weighted and then introduced into the medium continuously stirred at $50 \mathrm{rpm}$ and allowed to swell for 120 min. Swollen samples were removed periodically $(0,1,5,10,15,30,60,90$ and $120 \mathrm{~min})$ and their net mass was determined by first blotting their surface with filter paper to remove adsorbed medium on the surface and then immediately weighing them on an electronic balance. Each swelling experiment was repeated two times and the average value was taken as the swelling degree.

\section{In vitro drug release}

The in vitro drug release test for microspheres was carried out using a USP XXIV (17) basket apparatus containing $900 \mathrm{~mL}$ of freshly prepared $0.1 \mathrm{~mol} \mathrm{~L}^{-1} \mathrm{HCl}$ maintained at $37 \pm 0.5^{\circ} \mathrm{C}$, as the medium and rotating the basket at $100 \mathrm{rpm}$. A suitable volume of the sample was withdrawn and filtered promptly through a membrane filter disc having an average pore diameter not greater than $1.0 \mu \mathrm{m}$, rejecting the first $1 \mathrm{~mL}$ of the filtrate. The absorbance of the resulting solution was then measured with a UV spectrophotometer. 


\section{RESULTS AND DISCUSSION}

\section{Chitosan microspheres}

After initial optimization of various process parameters, chitosan solutions $(0.5,1$ and $2 \%, \mathrm{~m} / \mathrm{m}$ ) were spray dried and examined. It was found that solutions with chitosan concentration higher than $1.5 \%$ were too viscous to be broken into drops with controlled morphology and size. As summarized in Table II, spray-dried drug-free chitosan microspheres were spherical in shape, with a mean particle size ranging from 2.5 to 4.1 $\mu \mathrm{m}$. It was clear from the study that the mean size of droplets formed by atomization was proportional to liquid viscosity and surface tension (18) and indirectly affected the spray-dried powder size. Fig. 1 shows the almost spherical form of microspheres, regardless of the chitosan concentration in aqueous solution. The microspheres were able to take up a good amount of water, reaching balanced swelling (about 65 and $80 \%$ for 0.5 and $1 \%, \mathrm{~m} / \mathrm{m}$, chitosan) after a 60 min incubation period.

On the basis of the preliminary studies, a number of batches (M1-M9, Table I) were planned. As given in Table III, EE for all batches was found to be above $85 \%$. The best EE $(98.9 \%)$ was obtained with batch M5. The particle size for all batches ranged from 2.19 to $4.36 \mu \mathrm{m}$. Batch M5 showed the highest yield of $42.3 \%$.

As shown in Fig. 2a, the more concentrated and more viscous chitosan solution led to spray-dried microspheres of higher swelling capacity. Batches M1 to M3 showed

Table II. Influence of chitosan concentration

\begin{tabular}{ccccc}
\hline \multicolumn{2}{c}{ Chitosan solution } & \multicolumn{2}{c}{ Chitosan microspheres (spray dried) } \\
\hline Concentration $(\%, m / m)$ & Viscosity (Pa s) & Particle shape & Particle size $(\mu \mathrm{m})$ & Swelling $(\%)$ \\
\hline 0.5 & 0.0244 & Spherical & 2.5 & 64 \\
1 & 0.1642 & Spherical & 4.1 & 80 \\
2 & 18.2000 & & Not formed & \\
\hline
\end{tabular}

a)

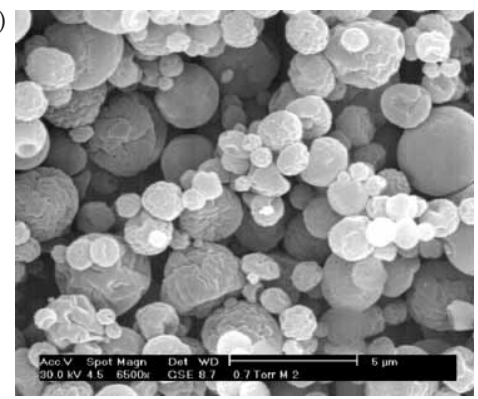

b)

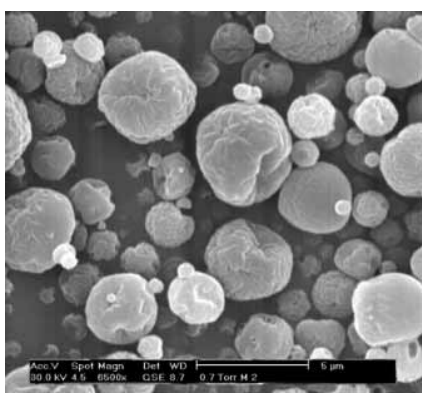

Fig. 1. SEM microphotographs of chitosan microspheres obtained by spray drying from aqueous solutions: a) $0.5 \%(\mathrm{~m} / \mathrm{m})$ chitosan; b) $1 \%(\mathrm{~m} / \mathrm{m})$ chitosan (magnification $6500 \mathrm{x}$ ). 
J. A. Raval et al.: Formulation and in vitro characterization of spray dried microspheres of amoxicillin, Acta Pharm. 60 (2010) 455-465.

Table III. Characteristics of uncrosslinked chitosan microspheres ${ }^{a}$

\begin{tabular}{|c|c|c|c|c|c|c|c|c|c|}
\hline & M1 & M2 & M3 & M4 & M5 & M6 & M7 & M8 & M9 \\
\hline$\overline{\mathrm{EE}}(\%)$ & 95.0 & 86.9 & 97.2 & 97.6 & 98.9 & 97.4 & 85.6 & 97.1 & 97.4 \\
\hline Yield (\%) & 37 & 28 & 31 & 36 & 42 & 20 & 25 & 28 & 15 \\
\hline $\begin{array}{l}\text { Particle size } \\
(\mu \mathrm{m})\end{array}$ & 2.19 & 2.37 & 2.34 & 3.42 & 3.49 & 3.56 & 4.36 & 4.11 & 4.29 \\
\hline$t_{80}(\min )$ & 33.18 & 34.18 & 35.24 & 64.58 & 49.07 & 61.80 & 67.28 & 68.39 & 122.73 \\
\hline $\begin{array}{l}\text { Mucoadhesion } \\
\text { after } 1 \mathrm{~h}(\%)\end{array}$ & 68 & 66 & 66 & 89 & 79 & 75 & 89 & 86 & 84 \\
\hline $\begin{array}{l}\text { Mucoadhesion } \\
\text { after } 4 \mathrm{~h}(\%)\end{array}$ & 56 & 51 & 52 & 78 & 67 & 64 & 74 & 68 & 67 \\
\hline
\end{tabular}

a All uncrosslinked microspheres were spherical.

swelling of 64,63 and $62 \%$, respectively, while batches M7 to M9 showed 88, 85 and $80 \%$ swelling. Fig. 3a shows that at the end of $1 \mathrm{~h}$ mucoadhesion of the microspheres was lowest (66\%) for batch M3 and highest (89\%) for batches M4 and M7. After $4 \mathrm{~h}$, batch M4 still showed the highest mucoadhesion (78\%).

In vitro drug release studies were carried out on batches M1 to M9. It was found that batches M1 to M3 released 72.3, 70.2 and $68.1 \%$ of the drug, respectively, after half and hour while batches M4 to M6 released 43.7, 48.9 and $46.5 \%$ of the drug, respectively. Drug release from batches M7 to M9 (38.4, 38.4 and $40.8 \%$, respectively) was lower than that from other batches after half and hour. Fig. 4a shows that most of the drug was released during the first two hours for all the batches. After $2 \mathrm{~h}$, batch M9 released $78.2 \%$ of the drug (the least of all the batches), while batch M1 released most all of the drug $(98.7 \%)$. It is evident that the degree of swelling affected the drug release. In order to control the drug release a further treatment with a crosslinking agent was planned and the batches were evaluated.
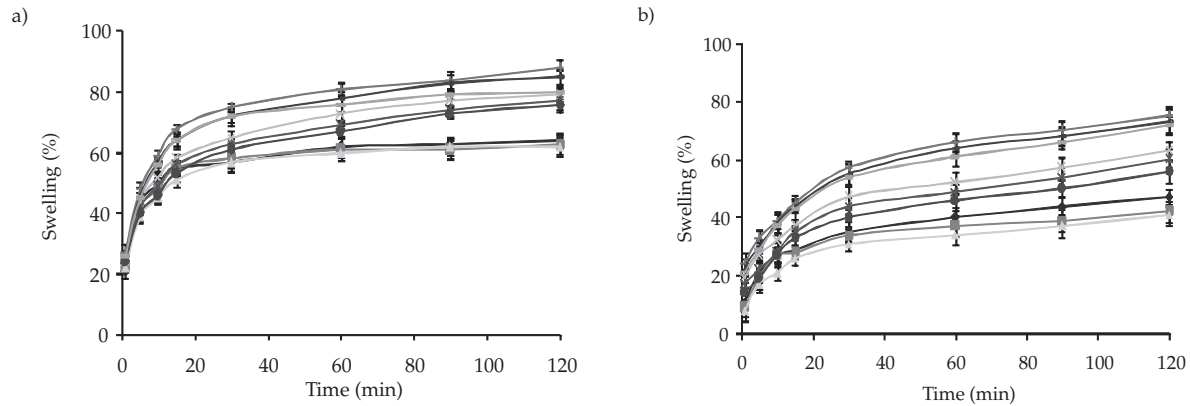

Fig. 2. Swelling of: a) uncrosslinked chitosan microspheres; b) crosslinked chitosan microspheres:

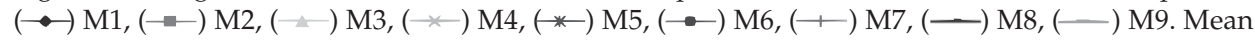
$\pm \mathrm{SD}, n=3$. 

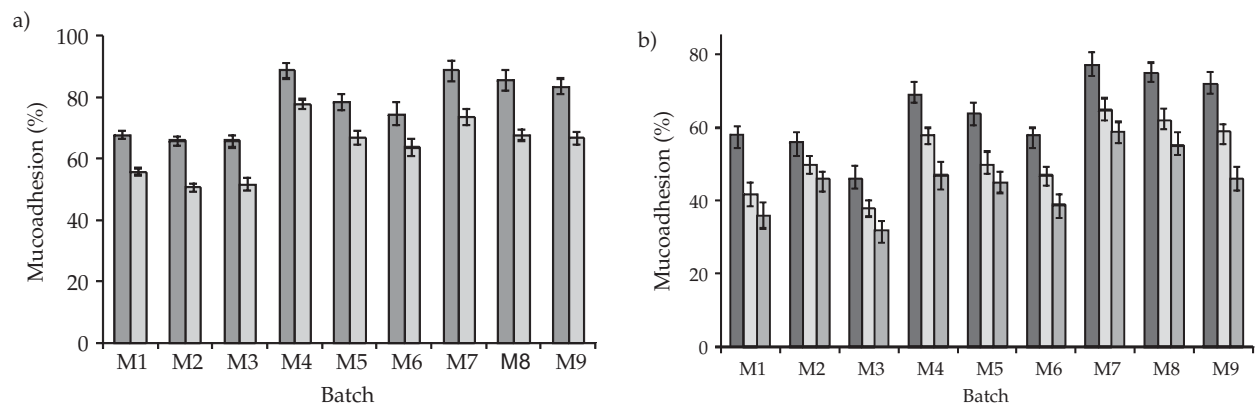

Fig. 3. Mucoadhesive property of: a) uncrosslinked chitosan microspheres after $(\square) 1 \mathrm{~h},(\square) 4 \mathrm{~h}$; b) crosslinked chitosan microspheres after: $(\square) 1 \mathrm{~h},(\square) 5 \mathrm{~h},(\square) 10 \mathrm{~h}$. Mean $\pm \mathrm{SD}, n=3$.
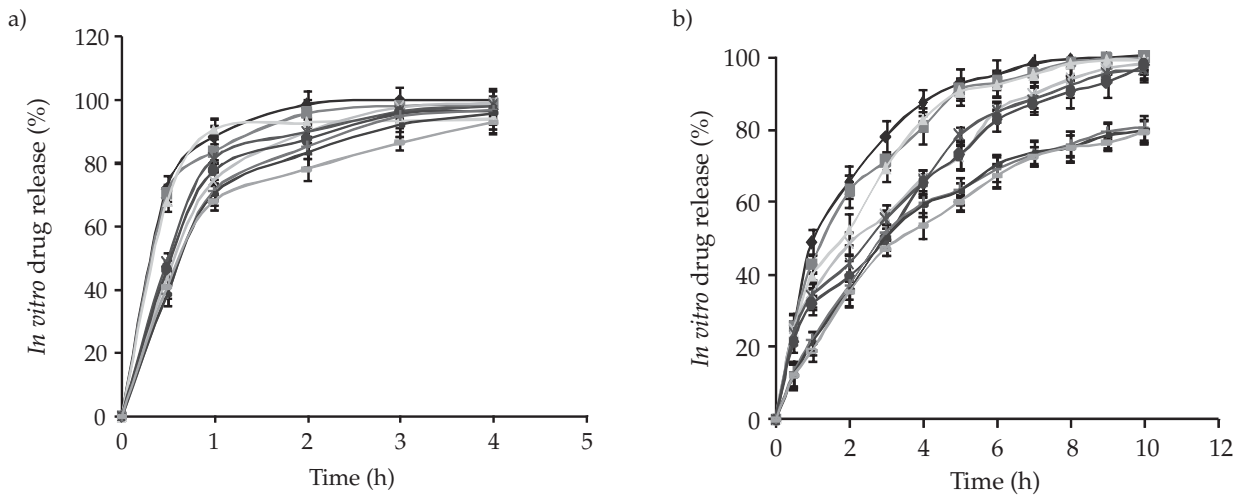

Fig. 4. In vitro drug release of: a) uncrosslinked chitosan microspheres; b) crosslinked chitosan microspheres: $(\bullet-) \mathrm{M} 1,(--) \mathrm{M} 2,(-)) \mathrm{M} 3,(-)) \mathrm{M} 4,(*)) \mathrm{M} 5,(\rightarrow-) \mathrm{M} 6,(\rightarrow) \mathrm{M} 7,(-)) \mathrm{M} 8$, $(-)$ M9. Mean \pm SD, $n=3$.

\section{Crosslinking of chitosan microspheres}

Chitosan microspheres were crosslinked with glutaraldehyde, the most commonly used aldehyde for crosslinking proteins (19) and also chitosan (20) for controlled delivery. As given in Table IV, EE for all batches was above $76 \%$. The best drug loading was obtained in batch M5 (91.6\%). Morphologically, all batches were spherical. The particle size of the batches ranged from 2.09 to $4.04 \mu \mathrm{m}$. Batch M5 showed the highest yield of $89.4 \%$ (calculation based on the initial amount of uncrosslinked microspheres taken).

The percent of swelling of crosslinked microspheres, as seen in Fig. 2b, showed a similar trend to that for uncrosslinked microspheres. The percent of swelling for batches M1 to M3 (47, 42 and $41 \%$, respectively) was almost half that of batches M7 to M9 (75, 73 and $72 \%$, respectively). 
Table IV. Characteristics of crosslinked chitosan microspheres ${ }^{a}$

\begin{tabular}{llllllllll}
\hline & M1 & M2 & M3 & M4 & M5 & M6 & M7 & M8 & M9 \\
\hline EE (\%) & 87.7 & 79.6 & 89.9 & 90.2 & 91.6 & 90.1 & 76.6 & 78.0 & 81.1 \\
Particle size & 2.09 & 2.15 & 2.21 & 3.08 & 3.32 & 3.39 & 4.04 & 3.69 & 3.46 \\
$(\mu \mathrm{m})$ & & & & & & & & & \\
Yield $(\%)$ & 66 & 87 & 77 & 78 & 89 & 78 & 69 & 70 & 75 \\
$t_{80}(\mathrm{~h})$ & 3.07 & 3.38 & 3.45 & 5.52 & 5.10 & 5.49 & 9.06 & 10.05 & 10.08 \\
\hline
\end{tabular}

a All crosslinked microspheres were spherical.

Fig. $3 \mathrm{~b}$ shows that after $1 \mathrm{~h}$ mucoadhesion of the microspheres was the lowest for batch M3, (46\%) and the highest for batch M7 (77\%). Even, after $10 \mathrm{~h}$, the same batch M7 showed the highest mucoadhesion (59\%), which could be ascribed to higher concentration of chitosan in this batch compared to batches M1 to M6.

In vitro drug release studies were carried out to find out the effect of crosslinking of batches M1-M9 on drug release. Fig. $4 \mathrm{~b}$ shows that the crosslinking process led to the sustaining of drug release from the microspheres. It was evident that crosslinking of batches M1 to M3 gave faster drug release compared to batches M7 to M9, which had higher concentration of the chitosan polymer, leading to more crosslinking and thus a more pronounced sustaining effect. The values of $t_{80}$, as given in Table IV, show that release of $80 \%$ of the drug was fast in batches M1 to M3 (3.1 to $3.5 \mathrm{~h}$ ). The values for batches M4 to M6 ranged from 5.1 to $5.5 \mathrm{~h}$ while those for batches M7 to M9 ranged from 9.1 to $10.1 \mathrm{~h}$. The aim of the study was to get $90 \%$ of drug release after $8 \mathrm{~h}$ of the in vitro drug release study (batches M4 to M6). In general, crosslinking reduced the EE, mucoadhesive property, and percent swelling and prolonged the in vitro drug release time.

Microspheres of batch M4 exhibited mucoadhesion of 69,58 and $47 \%$ after 1, 5 and $10 \mathrm{~h}$, respectively, $90.2 \%$ EE and $63 \%$ swelling. The $t_{80}$ value of $5.5 \mathrm{~h}$ indicated that the
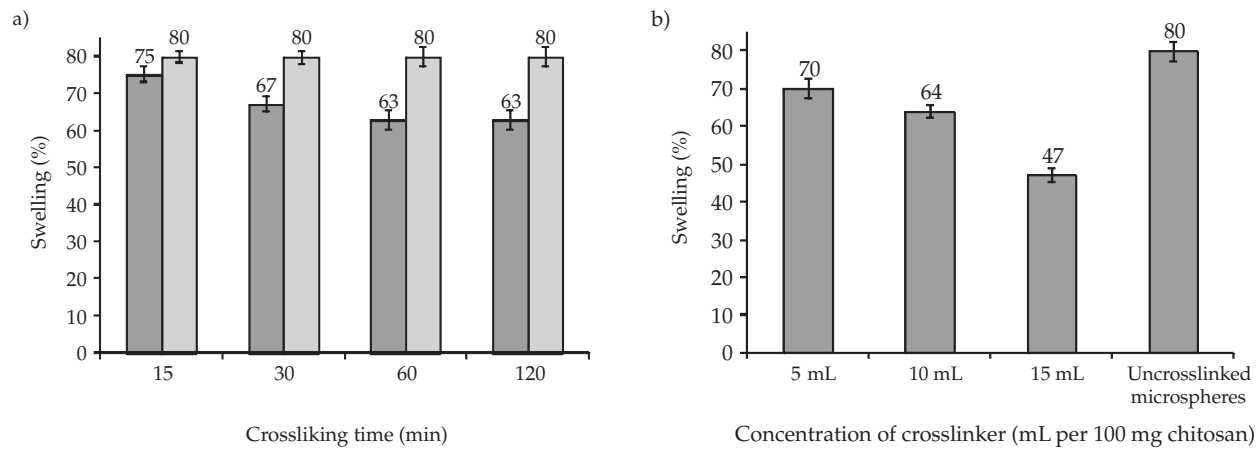

Fig. 5. Effect of: a) crosslinking time on water uptake of chitosan microspheres crosslinked with glutaraldehyde: $(\square)$ crosslinked, $(\square)$ uncrosslinked; b) effect of crosslinker concentration on water uptake of chitosan microspheres. Mean $\pm \mathrm{SD}, n=3$. 
mucoadhesive microspheres of amoxicillin could sustain drug release for more than $8 \mathrm{~h}$. This batch was further used for the optimization of crosslinking time and crosslinker concentration.

As shown in Fig. 5a, as the crosslinking time (15, 30, 60 and 120 min time points) increased, the degree of swelling decreased. The results show that a crosslinking time of 60 minutes was sufficient to get controlled drug release for $10 \mathrm{~h}$. During the optimization of crosslinker concentration (5,10 and $15 \mathrm{~mL}$ glutaraldehyde per $100 \mathrm{mg}$ chitosan), it was observed (Fig. 5b) that with the increase in crosslinker concentration, the colour of microspheres darkened from pale yellow to dark yellow along with a decrease in percent swelling of the spheres. As illustrated, for the same treatment duration (60 $\mathrm{min}$ ), the spray-dried chitosan microspheres showed their swelling capacity strongly reduced when the crosslinker concentration was increased from 5 to $15 \mathrm{~mL}$ per $100 \mathrm{mg}$ chitosan.

\section{CONCLUSIONS}

Chitosan microspheres with sustained release properties could be obtained by a spray drying process followed by chemical treatment with glutaraldehyde. The crosslinking density of the polymer network governed the swelling of the microspheres. It could be modified over a wide range through variation of different manufacturing conditions such as chitosan concentration in the solution used to prepare uncrosslinked chitosan microspheres, the crosslinking treatment duration and the concentration of the crosslinker reagent. A linear relationship was found between percent swelling and the in vitro drug release of chitosan microspheres, which might represent as a useful tool to control properties such as permeability to solutes and bioadhesiveness by suitable adjustment of the crosslinking extent of chitosan microspheres with glutaraldehyde. Finally, the results suggest that the spray-dried microspheres prepared from 1:2 drug to chitosan ratio dissolved in $0.5 \%$ acetic acid and followed by a chemical treatment with glutaraldehyde (10 mL per $100 \mathrm{mg}$ chitosan for $60 \mathrm{~min}$ ) may be a promising way to produce good spherical chitosan microspheres with a small particle size for controlled amoxicillin delivery.

\section{REFERENCES}

1. P. S. Rajinikanth and B. Mishra, Floating in situ gelling system of acetohydroxamic acid for clearance of H. pylori, Drug Dev. Ind. Pharm. 34 (2008) 577-587; DOI: 10.1080/03639040701831819.

2. N. Vakil and F. Megraud, Eradication therapy for Helicobacter pylori, Gastroenterology 133 (2007) 985-1001; DOI: 10.1053/j.gastro.2007.07.008.

3. J. R. Warren and B. Marshall, Unidentified curved bacilli on gastric epithelium in active chronic gastritis, Lancet 321 (1983) 1273-1275; DOI: 10.1016/S0140-6736(83)92719-8.

4. F. Magraud and H. Lamouliatte, Helicobacter pylori and duodenal ulcers, Dig. Dis. Sci. 37 (1992) 769-772; DOI: $10.1007 /$ BF01296437.

5. D. Forman, P. Webb and J. H. Personnet, H. pylori and gastric cancer, Lancet 343 (1994) 243-244; DOI: 10.1016/S0140-6736(94)91034-0. 
6. M. P. Cooreman, P. Krausgrill and K. J. Hengels, Local gastric and serum amoxicillin concentrations after different oral application forms, Antimicrob. Agents Chemother. 37 (1993) 1506-1509.

7. J. C. Atherton, A. Cockayne, M. Balsitis, G. E. Kirk, C. J. Hawley and R. C. Spiller, Detection of the intragastric sites at which Helicobacter pylori evades treatment with amoxicillin and cimetidine, Gut 36 (1995) 670-674; DOI: 10.1136/gut.36.5.670.

8. A. T. Axon, The role of acid inhibition in the treatment of Helicobacter pylori infection, Scand. J. Gastroenterol. 29 (1994) 16-23; DOI: 10.3109/00365529409105355.

9. A. K. Hilton and P. B. Deasy, In vitro and in vivo evaluation of an oral sustained-release floating dosage form of amoxicillin trihydrate, Int. J. Pharm. 86 (1992) 79-88; DOI: 10.1016/0378-5173(92) 90033-X.

10. N. Nagahara, Y. Akiyama, M. Nako, M. Tada, M. Kitano and Y. Ogawa, Mucoadhesive microspheres containing amoxicillin for clearance of Helicobacter pylori, Antimicrob. Agent Chemother. 42 (1998) 2492-2494.

11. C. M. Lehr, J. A. Bouwstra, E. H. Schacht and H. E. Junginger, In vitro evaluation of mucoadhesive properties of chitosan and some other natural polymers, Int. J. Pharm. 78 (1992) 43-48; DOI: 10.1016/0378-5173(92)90353-4.

12. L. Henriksen, K. L. Green, J. D. Smart, G. Smistad and J. Karlsen, Bioadhesion of hydrated chitosans: An in vitro and in vivo study, Int. J. Pharm. 145 (1996) 231-240; DOI: 10.1016/S0378-5173 (96)04776-X.

13. S. B. Rao and C. P. Sharma, Use of chitosan as a biomaterial: Studies on its safety and hemostatic potential, J. Biomed. Mater. Res. 34 (1997) 21-28; DOI: 10.1002/(SICI)1097-4636(199701)34:1 $<21::$ AID-JBM4>3.0.CO;2-P.

14. K. P. R. Chowdary and Y. S. Rao, Design and in vitro and in vivo evaluation of mucoadhesive microcapsules of glipizide for oral controlled release: A technical note, AAPS PharmSciTech. 4 (2003) article 39; DOI: 10.1208/pt040339.

15. Y. C. Huang, C. H. Chiang and M. K. Yeh, Optimizing formulation factors in preparing chitosan microparticles by spray-drying method, J. Microencapsul. 20 (2003) 247-260; DOI: 10.1080/ 02652040210162522.

16. P. R. Rege, R. J. Garmise and L. H. Block, Spray-dried chitinosans. Part I: preparation and characterization, Int. J. Pharm. 252 (2003) 41-51; DOI: 10.1016/S0378-5173(02)00604-X.

17. United States Pharmacopoeia 28, National Formulary 23, Asian Edition, USP Convention, Rockville (MD) 2005.

18. M. I. Ré, Microencapsulation by spray drying, Drying Tech. 16 (1998) 1195-1236; DOI: 10.1080/ 07373939808917460.

19. E. Bulgarelli, F. Forni and M. T. Bernabei, Casein/gelatin beads: I. Cross-linked solution composition effect on cross-linking degree, Int. J. Pharm. 190 (1999) 175-182; DOI: 10.1016/S0378-5173 (99)00262-8.

20. P. He, S. S. Davis and L. Illum, Chitosan microspheres prepared by spray-drying, Int. J. Pharm. 187 (1999) 53-65; DOI: 10.1016/S0378-5173(99)00125-8. 


\section{$S A \check{Z} E T A K$}

\section{Priprava i in vitro karakterizacija mikrosfera amoksicilina dobivenih metodom sušenja sprejom}

JIGNYASHA A. RAVAL, JAYVADAN K. PATEL i MADHABHAI M. PATEL

Cilj ovog rada bio je priprava mukoadhezivnih kitozanskih mikrosfera amoksicilina. Mikrosfere male veličine čestica i dobre sferičnosti pripravljene su metodom sušenja sprejom, te obradom s glutaraldehidom kao sredstvom za umrežavanje. Stupanj umrežavanja ovisio je o vremenu umrežavanja i koncentraciji sredstva za umrežavanje. Umreženim kitozanskim mikrosferama određen je oblik, veličina čestica, količina uklopljenog lijeka, postotak bubrenja i in vitro oslobađanje ljekovite tvari. Pripravak M4 s optimalnim svojstvima i kontroliranim oslobađanjem amoksicilina tijekom 10 sati pripravljen je pomoću smjese polimera omjera 1:2 otopljenih u razrijeđenoj octenoj kiselini, te umreženih pomoću glutraldehida. Povećanje koncentracije glutaraldehida i trajanja umrežavanja smanjuje sposobnost bubrenja kitozanskih mikrosfera, što je u izravnoj korelaciji s oslobađanjem lijeka iz mikročestica.

Ključne riječi: amoksicilin, produljeno oslobađanje, kitozan, mikrosfere dobivene sušenjem sprejom

S. K. Patel College of Pharmaceutical Education and Research, Ganpat University, Mehsana-Gozaria Highway, Kherva-382711, Gujarat, India

Nootan College of Pharmacy, Gujarat Technical University, Visnagar-384315, Gujarat, India

Kalol Institute of Pharmacy, Gujarat Technical University, B/h Old Janpath Hotel, National Highway, Kalol-382721, Gujarat, India 